\title{
Improving the Students' Activity and Achievement in Social Science Class by Using Film Media
}

\author{
Titik diyah Krisnawati, Aminudin Kasdi, Harmanto, Sukarman, Dyan Eka Pamungkas \\ Universitas Negeri Surabaya \\ Surabaya, Indonesia \\ Titikdiyah71@gmail.com
}

\begin{abstract}
This research is aimed to improve the students' activity and learning achievement in social science learning process. The students who get a low achievement during the process is caused by the failure of the teacher in choosing the appropriate teaching and learning activities. To overcome it, the teacher uses film as a media to make the students involve in the learning activities physically, emotionally and intellectually. This research uses a classroom action research with 3 cycles. There are 32 students as the subjects of this research. The data are obtained through class observation and test. The results show that the students are more actively involved in the process of learning social science and their achievement at the end of the process are increased.
\end{abstract}

Keywords-Activity; IPS; Natural; Artificial; film,; media

\section{INTRODUCTION}

The success of achieving the competence of a subject depends on several aspects. One of the aspects is the teachers' way in carrying out the learning process. The tendency of learning nowadays is still teacher-centered. Students are not actively involved in the learning process. As a result, the level of students' understanding of the learning material is low. In addition, the teacher does not use teaching aids in learning, so that learning is less meaningful, the students find it difficult to understand the material, and they become less serious in learning which impacts on the students' activities and learning outcomes. Teaching is not only about transferring the knowledge to the students but also about educating, teaching, guiding or facilitating students to find knowledge and learning experiences. Teaching process contains the message of developing the diverse potential of students and making them as recipients or users passive (consumer) [1].

Referring to this opinion, active learning is marked by a series of planned activities that involve students directly, comprehensively in physics, mental and emotional. This kind of thing is often ignored by the teacher because the teacher further improves the achievement of curriculum goals and targets. One of the teacher's efforts in creating an active, effective and enjoyable classroom atmosphere in learning is by using teaching aids. This can help the teacher to move, explain the picture of ideas in a material [2].
Social studies subjects are one of the non-exact subjects in elementary school. Learning these subjects is usually taught conventionally in almost every elementary school with classical methods such as lectures and group discussions. In general, the less the teachers use a learning media in the process the less the students take an interest in the learning process.

Related to these problems, armed with honesty and awareness of responsibility as educators, researchers tried to make efforts to improve learning through Classroom Action Research with alternative problem solving "Using film media to increase activity and learning outcomes in social studies learning for the third grade students of State Elementary School Masangan Wetan, Sukodono, Sidoarjo.

This study aims to find out how much the students' improvement in the ability of teachers in preparing learning plans by using picture media in social studies learning, to find out how much the increase in the ability of teachers in carrying out learning using image media in social studies learning, to find out how much increase student learning activities using picture media on social studies learning in class III, to find out how much an increase in student learning outcomes by using picture media in social studies learning in class III SDN Masangan Wetan, Sukodono, Sidoarjo.

The benefits of this study are presented as follows 1). For the students, is to equip students how to solve problems, make plans and maps of the home and school environment through improving students' understanding by activating students using picture media about making plans and maps of the environment. 2). For teachers, is to conduct classroom action research that is beneficial for the improvement of the learning process. In addition, teachers are more motivated to implement more various learning strategies, so learning material will be more interesting. 3). For schools, is to provide good resources in order to improve the learning process, so as to improve the quality of education. 4). For education, in general, is to improve the quality of education through the contribution of experience to classroom action research [3].

Learning activities is defined as activities given to learners in teaching and learning situations. This activity is 
designed to enable students to obtain the specified content so that various goals are set, especially the intent and curriculum can be achieved. Based on the opinion above, learning activities can be interpreted as a series of physical and mental activities that are carried out consciously by someone [4].

Learning activities according to Moeliono are grouped into several activities, namely as follows: a). Visual activities, for example, reading, observing, paying attention to pictures, and doing an experiment; b). Oral activities, for example, asking to give advice, expressing the opinions and discussing; c). Listening activities, for example, listening to a discussion and conversation, and discussing; d). Writing activities, for example, writing reports and copying; e). Drawing activities, for example, drawing, making graphs, and making diagrams; f). Metric activities, for example, conducting experiments; g). Mental activities, for example, remembering, analyzing, and making decisions; h). Emotional activities, for example, happy, brave, and passionate [5]. These types of activities are proposed based on the results of the analysis on the background of the problem. The problem in general in this research is "Does using the image media can increase the activity and learning achievements of students in social studies class III Masangan Wetan, Sukodono, Sidoarjo" . Furthermore, from the general problem the researchers develop it into several sub-problems, namely as follows: 1). How is the teacher's ability to carry out learning in social studies learning in class III Masangan Wetan, Sukodono, Sidoarjo. 2). How does the researchers apply the film media in the learning activity which involves physical activity, mental activity, and emotional activity.

Learning achievement is seen as the most important part of learning. The student learning achievement is defined as an essentially behavior change as learning outcomes in a broader sense covering cognitive, effective, and psychomotor fields [6]. Mention learning outcomes are the result of an interaction between learning and teaching. From the teacher's perspective, teaching action ends with a process of evaluating learning outcomes. In terms of students, learning outcomes are the end of teaching from the top of the learning process [7]. Mentions six types of cognitive domain behavior, as follows: a). Knowledge, achieving memory ability about things that have been learned and stored in memory. Knowledge is related to facts, events, understanding of rules, theories, principles, or methods, b). Understanding, includes the ability to capture the meaning of things, c). Application, includes the ability to apply methods and rules to deal with real and new problems [8], for example, using the principle, d). Analysis, includes the ability to detail an entity into parts so that the overall structure can be understood well, for example, reducing the problem to the smallest part, e). Synthesis, includes the ability to form a new pattern, for example, the ability to compile a program, f). Evaluation, includes the ability to form opinions about several things based on certain criteria, for example, the ability to assess the results of tests [9].

Based on the understanding of learning achievement above, it is concluded that learning achievements are the abilities that students have after receiving their learning experience. Learning achievements can be seen through evaluation activities that aim to obtain verification data that will indicate the level of students' ability in achieving learning goals. The learning achievement examined in this research are the results of learning Social Sciences Making a Plan and Map of Home and School Environments which includes three levels, namely knowledge, understanding and application [10].

Citing factors that influence learning achievement, as follows: a). Internal factors are factors that exist in individuals who are learning include physical factors and psychological factors, b). External factors are factors that exist outside the individual include family factors, school factors, and community factors [10]. Based on the factors that influence the learning achievement above, the researchers use external factors in the form of the use of image media in the learning of Social Sciences about "Natural and Artificial Environments ".

Media can be interpreted as everything that can be used to distribute messages (message), stimulate the mind, feelings, attention, and willingness of students so that it can encourage the learning process [11]. Learning media is anything that can be used to channel messages (learning material) so that it can stimulate the attention, interests, thoughts, and feelings of students (students) in learning activities to achieve certain learning goals. For example, pictures, charts, models, films, videos, computers and so on [12].

From this understanding, it can be concluded that media images are media that are not protected and can be enjoyed by everyone as a move from the actual situation of people, atmosphere, place, goods, scenery, and other objects.

The advantages of image media are generally cheap, easy to obtain, easy to use, can clarify a problem, more realistic, can help overcome the limitations of observation, and can overcome space limitations. While the lack of image media is merely a visual medium, the size of the image is often not appropriate for teaching in large groups, requiring the availability of skills and foresight of teachers to be able to use it [13].

\section{METHODS}

This study is a classroom action research adapted from the Kemmis \& Mc spiral model Taggart. In the process, the researchers participate directly from beginning to end of the process. The researchers try to understand what is happening while involved in a process of change and improvement [14]. 
The time of the research conducted is from the second week of April 2018 until the first week of May 2018 at the State Elementary School Masangan Wetan, Sukodono, Sidoarjo. The subjects of research are 32 students of class III, consist of 16 male and 16 female students. The data are obtained through (1) observation sheet of learning activities, and (2) test of learning achievement. The research procedure includes: (1) the pre-action stage, and (2) the implementation phase of the action consisting of three cycles. Each cycle is planned (plan), implemented (action), observed (observation), and reflected of the results of the action (reflection) [15].

The full steps of the activity begin with preparing the research instrument, preparing a Lesson Plan (RPP), and creating a media learning "Natural and Artificial Environments". In doubt - enforcing the hydrosphere learning on the material using instructional media "Natural and Artificial Environments" is known as observing and documenting the data related to the activity and results of social studies learning of the students throughout the learning process. The teacher explains the Natural and Artificial Environments, then the students carry out group discussions. After finishing it, then the students are asked to present the results of the discussion and the other groups responded.

As the end of the activity is reflection that is done to see the results of the implementation of learning as a material to plan actions in the next cycle. The following is a description of the Class Action Research cycle referred to above.

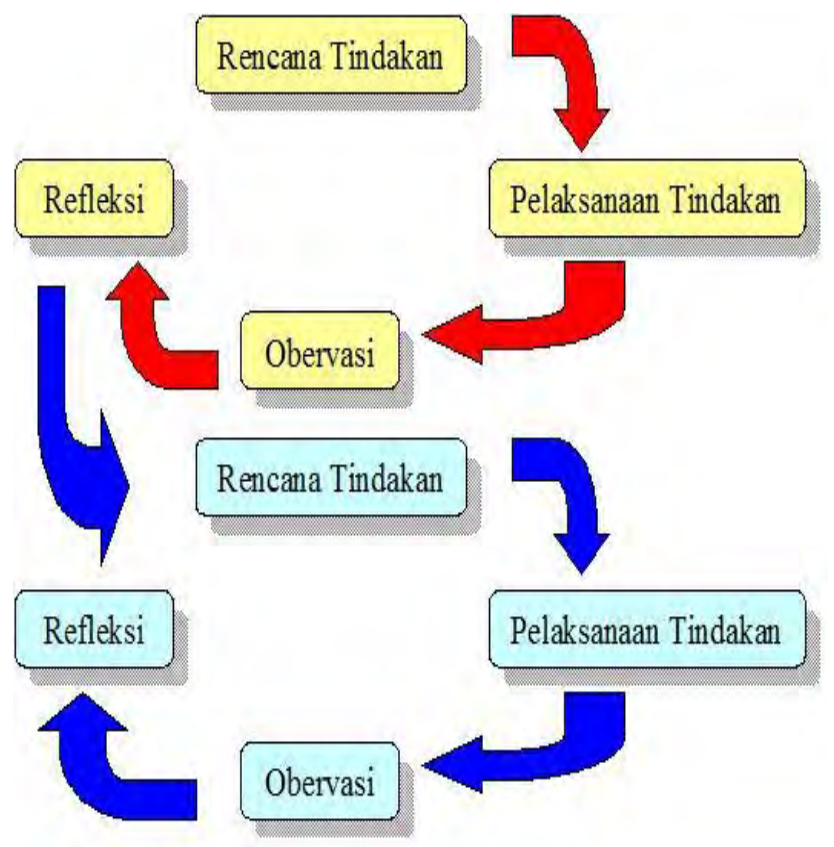

Figure 1. Kemmis \& Mc Class Action Research Cycle. Taggart

\section{RESULTS AND DISCUSSION}

Based on the results of preliminary observations, the learning activities of students in the less category with a mean of 36.5. A total of 17 students and students (53.13\%) showed low learning activities characterized by showing no attention to most of the learning time, not interested in the explanation given by the teacher, and shows less interest in learning. In addition, the learning outcomes of class VII-D students are low with an average learning result of 60.25 , as many as 25 students $(78.13 \%)$ show learning outcomes under the Minimum Criteria of Examination (KKM).

\section{TABLE 1. Learning Activities}

\begin{tabular}{|c|c|c|c|c|c|c|c|c|}
\hline & Oberres.872 & & Sites I I I I & & StewI & & Slltex II & \\
\hline Buteng & Jumlepresth & $\%$ & 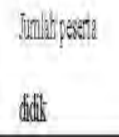 & 9 & 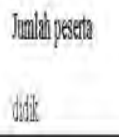 & $\%$ & 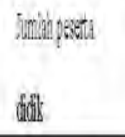 & in \\
\hline Tinged & 15 & 40,87 & 17 & 331.2 & $B$ & 71.8 .8 & $y$ & $4 P^{\circ}$ \\
\hline Readen & 1) & 3,13 & 16 & 468. & 9 & 28,13 & $j$ & $13 / 3$ \\
\hline
\end{tabular}

After the action is taken by using the learning media " Hidrosfer Window " in Cycle I, the learning activities of students experienced a slight increase compared to the initial observation, only 15 students show low learning activity with the percentage of successful actions reaching a mean of 59 in the sufficient category. In Cycle II, it increased from 15 students to 9 people who show learning activity is low with the percentage of successful actions reaching 72 in the good category. Cycle III exceeded the target of 5 people, which showed low learning activity from the target of 7 people in the low category, the average percentage of successful actions reaching 81 in the very good category. Thus, it is said that the use of learning media can improve learning activities.

TABLE 2. Level of Success of Learning Activities

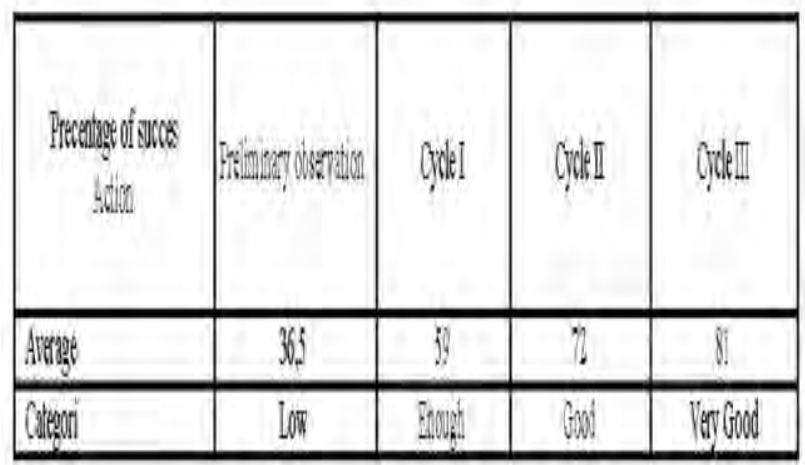


Along with the increasing of learning activity from cycle I to cycle III, the average increase in learning achievement of the first cycle is only slightly with a mean of 65 in the sufficient category. In cycle II, the average learning achievement is 73.25 (adequate category), and in cycle III, it shows 81.72 (very good category).

TABLE 3. Learning outcomes

\begin{tabular}{|c|c|c|c|c|}
\hline Result & Preliminary observation & Cycle I & CycleII & Cycle II \\
\hline Average & 60,25 & 65 & 73,25 & 81,72 \\
\hline Categori & Low & Enough & Good & Very Grood \\
\hline
\end{tabular}

The results of the research in Cycle I show the learning activities only increased slightly due to students enjoying too much of the pictures presented and the time for group discussion was only small and only dominated by two of the eight groups; thus the students' understanding of the material is very small and of course when measuring the results of social studies learning shows a slight increase as well. For this reason, the teacher needs to improve learning in Cycle II.

In Cycle II learning activities are increased because the students began to actively discuss to analyze images and are better able to manage the time and presentation of the results of the discussion began to appear not only dominated by certain groups. Understanding of the material is better so learning outcomes have increased significantly. Cycle III exceeds the target because the learning process went smoothly and the students enjoyed it very much when the test was done the results exceeded the target set (average 81.72) which is 75 .

\section{CONCLUSION}

Based on the results of the study prove that the use of learning media "Natural and Artificial Environments" is able to increase the learning activities of students. Evident from each cycle shows the improvement in a significant way in the activities and learning outcomes of students. Learning activities in Cycle I, which initially 17 people $(53.13 \%)$ showed high learning activities with a mean of 59 and the success level category, increased to 23 people (71.87\%) showed high learning activities with a mean of 72 and the level of success was good in Cycle II, and in Cycle III to 27 people $(84.27 \%)$ showed high learning activities with a mean of 81 and the category of success was very good.
The significant improvement in learning achievement along with increased learning activities. In cycle I, the average learning achievement are only 65 in the sufficient category, in cycle II with a mean of 73.25 in the good category, and finally the average learning outcomes in cycle III were 81.72 in the very good category.

\section{REFERENCES}

[1] A. M. Sardiman, Interaksi \& motivasi belajar mengajar: Rajagrafindo Persada (Rajawali Pers), 2004.

[2] A. Ramali and K. S. Pamoentjak, "Kamus kedokteran," Djambatan, Jakarta, 2000.

[3] M. Allaby, Macmillan dictionary of the environment: Macmillan Press Ltd., 1994.

[4] A. Fuad, "Prinsip-prinsip masalah pencemaran lingkungan," ed: Jakarta: Ghalia Indonesia, 1989.

[5] A. M. Moeliono, "Kamus besar bahasa Indonesia," Jakarta: Balai Pustaka, 1988.

[6] O. Hamalik, Proses belajar mengajar: Bumi Aksara, 2004.

[7] O. U. Effendy, "Ilmu, teori dan filsafat komunikasi," ed: Bandung: PT. Citra Aditya Bakti, 2003.

[8] Hidayati, "Pendidikan Ilmu Pengetahuan Sosial di Sekolah Dasar," Yogyakarta: Universitas Negeri Yogyakarta, 2004

[9] S. McNaughton and L. L. Wolf, "Ekologi Umum," Penerjemah Soenaryo. Gadjah Mada University Press, Yogyakarta, 1990.

[10] A. Rohani, Pengelolaan pengajaran: Rineka Cipta, 1991.

[11] D. K. Rusman and C. Riyana, "Pembelajaran Berbasis Teknologi Informasi dan Komunikasi," Bandung: Rajawali Pers, 2011.

[12] O. Soemarwoto, Analisis mengenai dampak lingkungan: Gajah Mada University Press, 1999.

[13] St. Munajat Danusaputra. Pengertian Lingkungan Menurut Para Ahli. Jakarta: PT Raja Grafindo Persada, 2008.

[14] M. Yamin, "Profesionalisasi guru dan implementasi kurikulum berbasis kompetensi," Jakarta: Gaung Persada Pers, 2006. 